\title{
<総＼cjkstart説 $>$
}

\section{酸化リポタンパク質とレシチン・ \\ コレステロール アシルトランスフェラーゼ}

\author{
東北大学大学院 農学研究科 \\ 神山伸・古川勇次
}

\section{はじめに}

血漿 HDL レベルと虚血性心疾患（Coronary Heart Disease；CHD）との間に逆相関 があることは疫学調查によって確証されており，HDLによるこの抗動脈硬化作用が末梢 細胞からの過剩コレステロールの除去作用, いわゆるコレステロール逆転送系（ReverseCholesterol Transport) に関連していることは広く知られている。

血漿中のフリーラジカルによって，LDL と同様にHDLも酸化を受けることが知られて おり，最近になって酸化による HDL 代謝の変化と，その動脈硬化症進展におよぼす影響 について焦点が当てられつつある。

本稿では，血漿中のフリーラジカルの生成とそれによるリポタンパク質の酸化が HDL による脂質逆転送系へどのような影響を及ぼしているかを検討し，とくに HDL上で作用 している酵素である Lecithin-cholesterol acyltransferase (LCAT, [EC 2.3.1.43]) の代 謝に注目して紹介する。

\section{LCAT}

細胞のコレステロールが HDLによるコレステロール逆転送系によって排出されている ことはGlomsetによって最初に認められだ”。細胞のコレステロールはHDL に移行した のちコレステロールェステル（CE）の形になって運搬されるが，この転換に関与してい る酵素が LCATである。

LCAT は専ら HDL 表面に結合して存在し, 主要な反応はPhosphatidylcholine (PC) の sn-2位のアシル基をコレステロールの3 $\beta$-OH 基に転移することにより CEと Lysoph

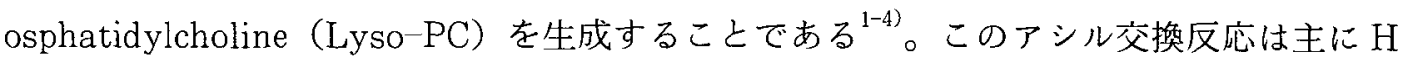
DL 上で起こり，HDL の主要なアポリポタンパク質である apo A-I 補酵素として行わ れる ${ }^{5)}$ 。泡沫細胞を含む種々末梢細胞のコレステロールは前述のコレステロール逆転送 系によって肝臓に運ばれるものと考えられているが，その第一段階であるコレステロール 引き抜きにおいて，HDL 表面のコレステロールをエステル化するこのLCAT 反応は細胞 膜から HDL へのコレステロールの移行を持続させる上で重要な役割を果している。血漿 
リポタンパク質中のCEはそのほとんどがLCATによって生成したあのでありままたそれ によって間接的に種々の組織や細胞のコレステロール，CEのレベルを調節しているもの と考えられている。

通常, LCATは，原始型（nascent） HDL から小型の $\mathrm{HDL}_{3}$ ，さらに大型の $\mathrm{HDL}_{2}$ へ と成熟する過程を通して, LDL, VLDL の過剩のコレステロールの除去, および細胞膜 から HDL へのコレステロール引き抜きに関与しているむのと考えられている。LCAT 欠 損症患者では，原始型 HDL および小型 HDL が増加し，また小型の高密度化した LDL の生成, コレステロール含量の増加した異常赤血球の増加などの变化がみられる に, LCAT 欠損症患者では, 種々の組織でコレステロールとリン脂質が蓄積されやすい ため，動脈硬化症易発性であると考えられている。

LCAT は分子量65,000〜69,000で，24\%（W/W）の糖を含有した糖タンパク質であり， 糖含有量の差により分子量に変動がある゙.8)。LCAT のアミ，酸配列は McLean 等によっ て明らかにされ゙，それによると416のアミノ酸残基（分子量47090）からなる polypeptide 鎖で構成されている。6つの Cystein 残基と 4 つの糖鎖結合部位をもっており, 膵, 舌 lipase との相同性がみられる $\mathrm{I}_{178} \mathrm{GHSLG}_{183}$ の hexapeptide が活性中心として機能している。 $\mathrm{CyS}_{530}-\mathrm{Cys}_{74}$ と $\mathrm{CyS}_{313}-\mathrm{CyS}_{356}$ に disulfide 架橋をむっており, $\mathrm{Asn}_{20}, \mathrm{Asn}_{84}, \mathrm{Asn}_{272}, \mathrm{Asn}_{384}$ が糖鎖結合部位として機能している。

LCAT の酵素化学的性質として，この䤉素は精製された状態ではイオン強度の低い条 件では安定であるものの不活性であり，一方イオン強度の高い条件では不安定であるが， 基質または補酸素の存在で安定となり, 活性を発現できる ${ }^{10)}$ 。LCATの反応速度は酵素の HDLへの結合性によって大きく左右される。酵素の結合性にもっとも大きく影響してい るのはりポタンパク質粒子の大きさであり，粒子サイズの大きい HDL く，一方粒子サイズの小さい HDL や原始型 HDL は良好な基質となる。LCAT の結合性 は構成アポリポタンパク質組成 ${ }^{5,11)}$ や構成リン脂質の種類 ${ }^{12-15)}$ にって影響されることが 知られている。また，LCAT の PC に対する基質特異性は16:0-18:1，16:0-18:2，18:0-18:0 で構成される PCに対して反応性が高く，また活性は粒子中の PC の分子種の相対含量に よって大きく影響されるが，これはLCAT の基質分子（HDLあるいはリポソーム）相互 間における転移活性が規定されるためであると考えられる ${ }^{12)}$ 。基質分子中に関与する apo A-I がこの酵素の基質分子間の転移活性を促進する作用を持ち，これがこの酵素の活性の 発現となっている。

\section{2. リポタンパク質の酸化と血漿 LCAT 活性}

動脈硬化の成立機序には多くの因子が関与していることが知られており，様々な角度か らのアプローチがなされている。動脈硬化初期病変に果たしている酸化 LDL の役割につ 
いての研究は枚挙に睱が無く，現在では中心的な位置を占めるに至っているが，HDL 代謝に 与える影響についてはまだ十分に検討されておらず，今後の解明を待つところとなっている。

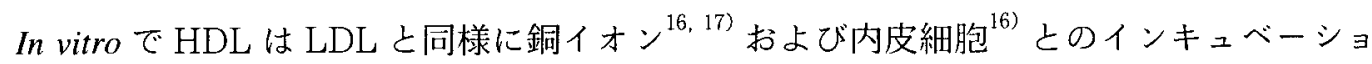
ンによって酸化を開始させることができる。Wang らはHDL の酸化によって免疫反応性 が変化することを示しており ${ }^{18)}$ ，これは apo A-I の架橋形成による変化に基づくことが 確認されており ${ }^{19)}$ ，また酸化によって apo A-I の二次構造が変化すること屯報告されて いる ${ }^{20)}$ 。酸化 HDL は酸化 LDL よりありンパ球に対する細胞毒性が少ないと報告されて いるが゚ $り^{22-24)}$, さらに, HDL中の apo A-I のマロンジアルデヒドおよび酸化による修飾によっ て ${ }^{25)}$ ， あるいは血漿を喫煙下の様な酸化ストレスに置くことにより ${ }^{25,27)}$, その LCAT の活 性化作用が失われるとの報告や，また酸化 HDL はマクロファージ内にエステル化されてい ないコレステロールを蓄積させるとの報告がある ${ }^{28)}$ 。すなわち, HDLか酸化されることによっ て HDL の持つ抗動脈硬化作用が消失し, 動脈硬化が促進される可能性が示されている。

以下，ラジカル開始剂（AAPH；2，2'-Azobis-amidinopropane dihydrochloride）で 血漿を酸化処理した場合に起こる脂質過酸化と血漿 LCAT 活性の変動を検討した筆者ら の実験結果 $\left.{ }^{29}, 30\right)$ をとに，血漿中でのフリーラジカルの生成が血漿 LCAT 活性に及淮す 影響について述べてみたい。

\section{2-1 AAPH による血墏の酸化と LCAT 活性の変動}

AAPHによってヒト血漿中にフリーラジカルを生成させた場合, Fig. 1-aに示した

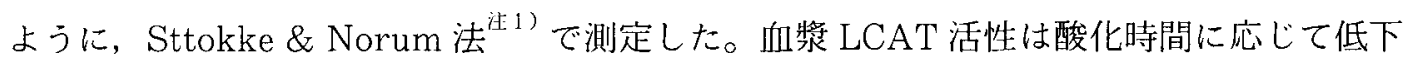
し，24時間後にはコントロールの血漿の57\%まで低下した。コントロールの血漿において あインキュベーション時間とともに活性が低下しているが，これは酸化時間に合わせた長 時間のインキュベーションによって一部の酵素が失活したためと思われる。なお，血漿の 酸化処理はその間に LCAT 反応が起こらないょう, 可逆的に LCATを失活化させるDTN B (5,5'-dithiobis (2-nitrobenzoic acid)) の存在下で行った。TBARS 值で推定した過 酸化脂質量はコントロールの血漿では増加しなかったのに対し, 酸化処理を行った血漿で は酸化処理 5 時間まで直線的に増加を示し，その後むコントロールの血漿に対し有意に高 值を示した（Fig. 1-b)。

注 1. Stokke and Norum法 ${ }^{56,57)}$

全血漿りポタンパク質に放射性コレステロールを均一に分布させた後，血漿に存在する 内因性の酵素（LCAT），基質（HDL），補酵素（apo A-I）により醉素反応を行い， CE 生成率を計算する。活性值はin vivo での実際の血漿のコレステロールエステル化反応の 回転率を近似的に表したものであり，LCAT自身の酵素量を表すむのではない。 
(a) LCAT activity

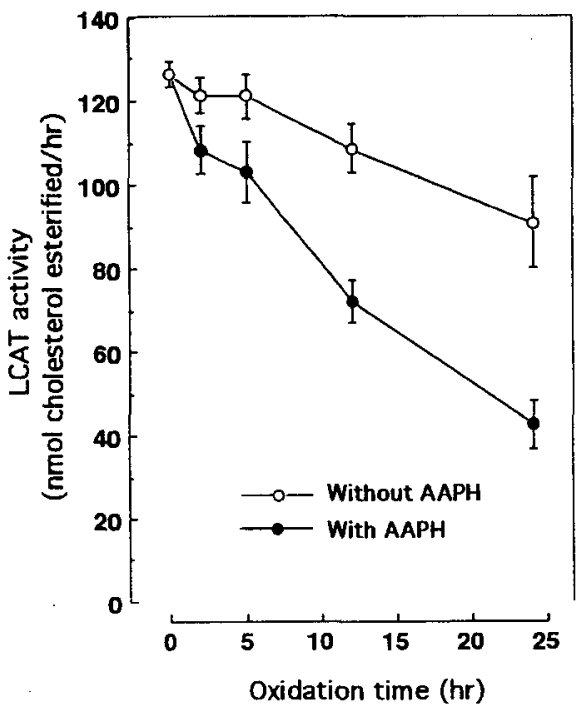

(b) TBARS value

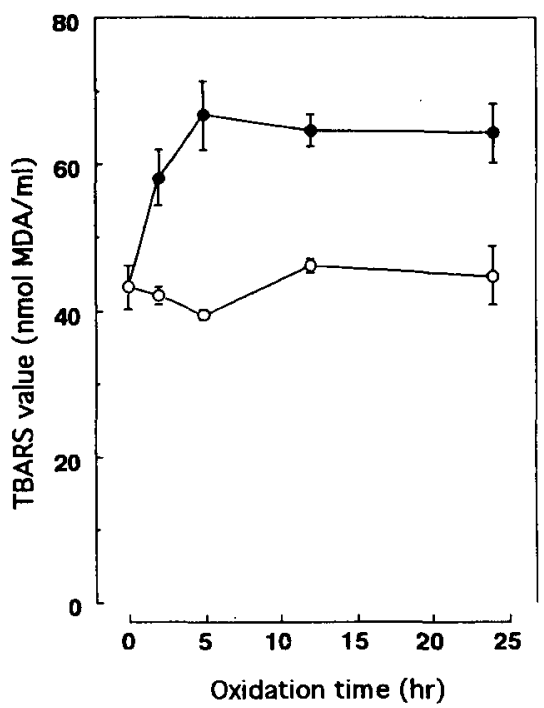

Fig. 1. Effect of oxidation of plasma on LCAT activity (a) and TBARS value (b).

Plasma collected from normolipidemic subjects was treated with $2 \mathrm{mM} \mathrm{AAPH}$ at $37^{\circ} \mathrm{C}$ for various incubation times. (a) LCAT activity was measured by Stokke and Norum's method. (b) TBARS value was measured using 1,1,3,3,-tetraethoxypropane as standard according to Yagi's method. Values shown are mean \pm SEM of triplicate observations. Activity was calculated as nmol esterified cholesterol in $1 \mathrm{ml}$ plasma for every $1 \mathrm{hr}$ of reaction time. Open circles, plasma incubated without AAPH ; closed circles, plasma incubated with AAPH. (文献30)

(a) Dose-response

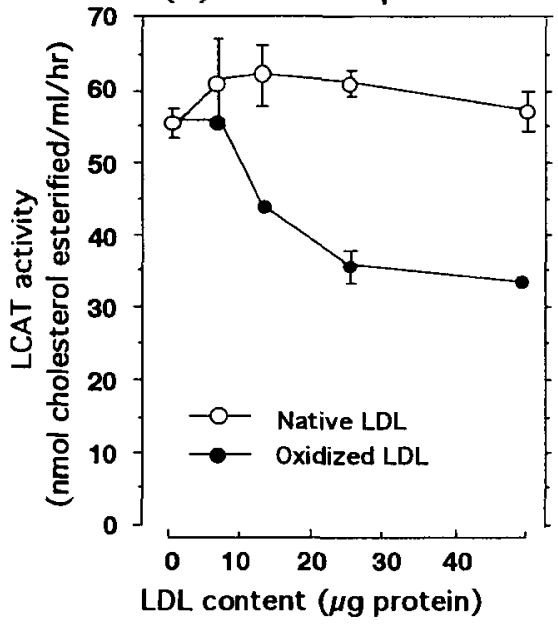

(b) Oxidation time

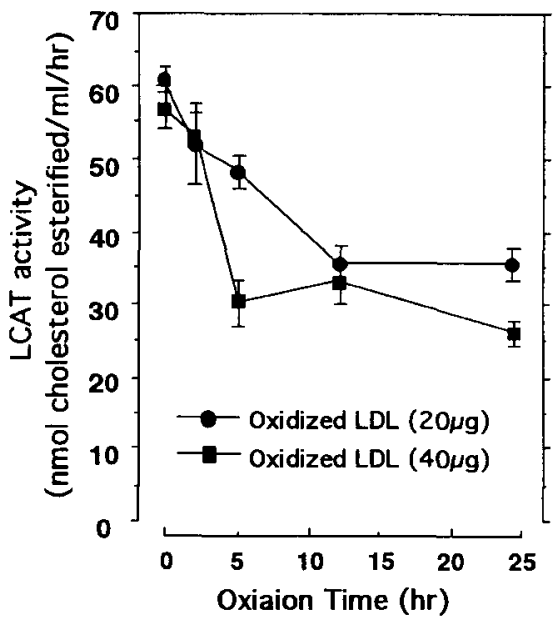

Fig. 2. Effects of oxidized LDL on LCAT Activity.

Oxidized LDL samples were prepared by incubation with $5 \mu \mathrm{M} \mathrm{CuSO}_{4}$ for $12 \mathrm{~h}$ (a) or various times (b) at $37^{\circ} \mathrm{C}$. LCAT activity was measured by Stokke and Norum's method. LDL or oxidized LDL were added to the medium which was then incubated under standard assay conditions. Activity was calculated as the ratio of cholesterol counts to total radio activity. Values shown are mean \pm SEM of triplicate observations. (a) Open circles, native LDL added. Closed circles, $12 \mathrm{~h}$-oxidized LDL added. (b) Circles, $20 \mu \mathrm{g}$ of oxidized LDL added. Squares, $40 \mu \mathrm{g}$ of oxidized LDL added. (文献29より改変) 
ここで行った AAPH 添加による血漿の酸化では，全血漿を酸化したものであるため， 過酸化による影響はリポタンパク質のみならず，LCAT 酵素自身をはじめ種々の血漿成 分にもあたらされるあのと考えられる。そこで, 別に単離したリポタンパク質を酸化好理 し，血漿中に添加することにより，血漿中での酸化りポタンパク質の存在が血漿 LCAT 活性に及ぼす影響を検討した。Fig. 2 に示したように，酸化 LDL を血漿に添加した場合， LCAT活性は添加した酸化 LDL の量（a）および酸化の程度（b）に応じて低下を示し たことから，酸化 LDL の生成が血漿 LCAT 活性に大きく影響を及ぼすことが示された。

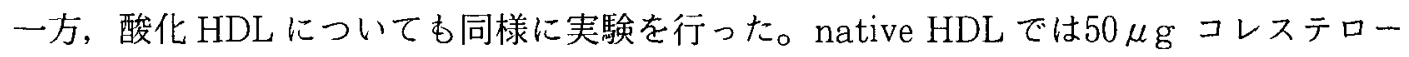
ル（血漿中の HDL と等量）の添加まで血漿 LCAT 活性に影響を与えなかったが, 酸化 HDL では, 酸化 LDL の場合（Fig. 2）と同様に添加量に応じて直線的に LCAT 活性を 阻害した（Fig. 3)。

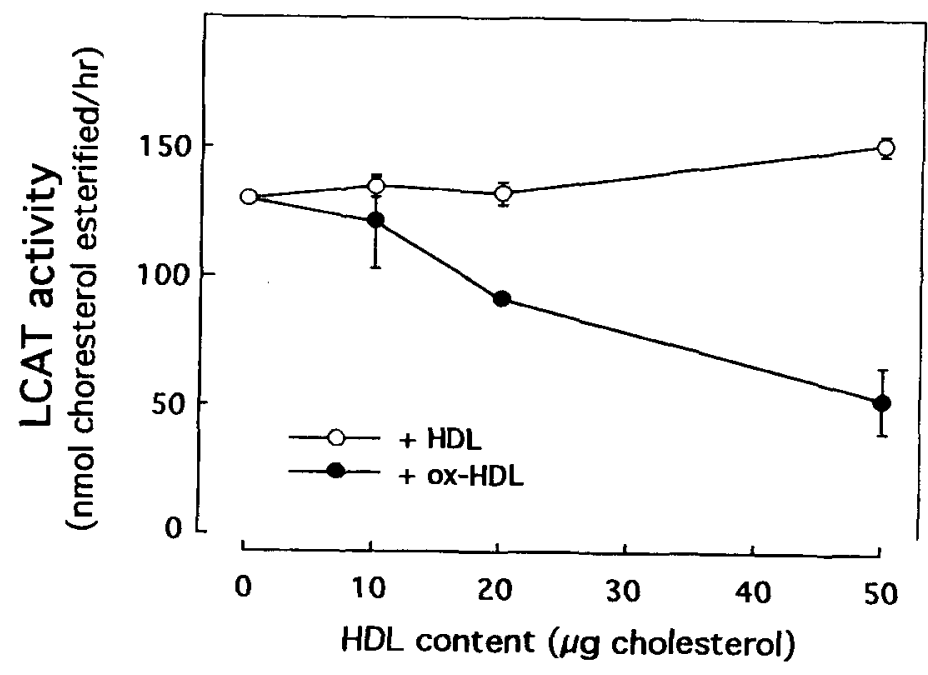

Fig. 3. Effects of oxidized HDL on plasma LCAT activity.

Oxidized HDL samples were prepared by incubation with $2 \mathrm{mM} \mathrm{AAPH}$ for $12 \mathrm{~h}$ at $37^{\circ} \mathrm{C}$. LCAT activity was measured by Stokke and Norum's method. Either HDL or oxidized HDL was added to the medium, and it was then incubated under standard assay conditions. Activity was calculated as nmol esterified cholesterol in $1 \mathrm{ml}$ plasma for every $1 \mathrm{hr}$ of reaction time. Values shown are mean \pm SEM of triplicate observations. Open circles, native HDL added; closed circles, oxidized HDL added. (文献30)

\section{2-2ＰCとコレステロールの酸化が LCAT 活性におよばす影響}

次に，反応をより明確化するために，精製 LCAT および精製 apo A-I を用い，基質と して PCとコレステロールから構成されるリポソームを用いた反応系（標準 LCAT 活性 
(a) LCAT activity

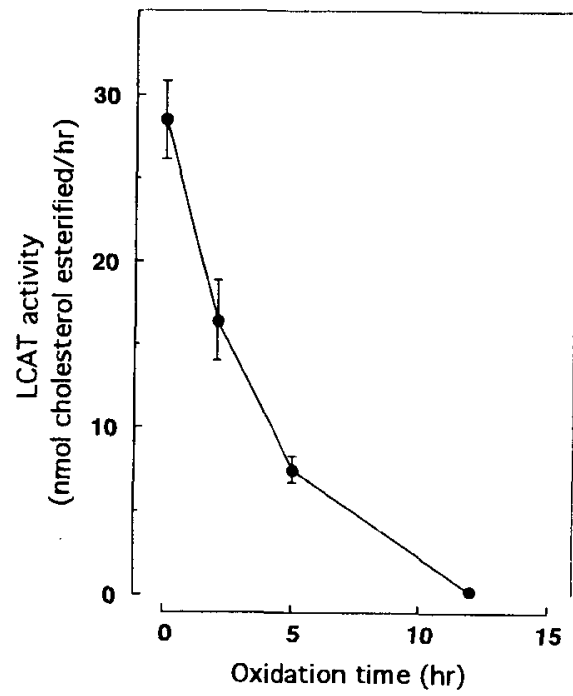

(b) TBARS value

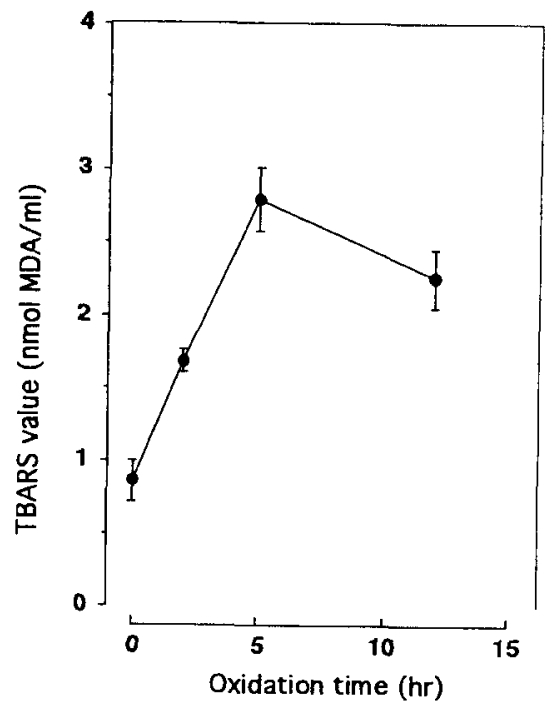

Fig. 4. Effect of oxidation of substrate vesicles on LCAT activity (a) and TBARS value (b). Vesicle solutions were prepared and oxidized by incubation with $2 \mathrm{mM}$ AAPH for various times at $37^{\circ} \mathrm{C}$. Values shown are mean \pm SEM of triplicate observations. (a) LCAT activity was measured using purified enzyme and cofactor in vesicle solution. Activity was calculated as nmol esterified cholesterol in $1 \mathrm{ml}$ solution for every $1 \mathrm{hr}$ of reaction time. (b) TBARS value was measured using 1,1,3,3,-tetraethoxypropane, which produces malondialdehyde (MDA), as standard according to Yagi's method. (文献30)

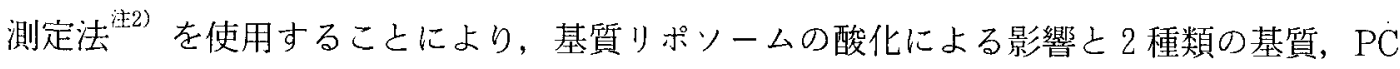
とコレステロール，のどちらの酸化がLCAT 活性により大きな影響を及ぼすかを検討し た。

まず，基質リポソームを $2 \mathrm{mM}$ の AAPH で酸化した場合の LCAT 活性の变動を検討し た。LCAT 活性は基質りポソームの酸化時間に応じて低下し，12時間酸化のリポソーム ではほぼ完全に阻害され（Fig. 4-a)，TBARS 值は酸化時間 5 時間まで直線的に増加し た（Fig. 4-b )。この実験はリポソーム溶液だけを酸化した（LCAT， apo A-I を含まな い）ので，この活性の低下は主に基質である脂質の酸化によっており，酵素 LCAT 或い は apo A-I の酸化変性によるむのではない屯のと考えられる。この結果は基質りポソー ムだけの軽度の酸化が酵素活性に大きく影響したことを示しており，LCAT 活性の修飾

注 2。標準 LCAT 活性测定法, ${ }^{88}$

精製酵素 LCAT, 精製補酵素 apo A-I，および PC とコレステロールから構成されるリ ポソームを基質として用いる酵素反応系で，精製酸素を用いる実験系および精製過程にお ける酵素活性の測定に適した方法であり，酵素反応に及ぼす他の因子の影響が少ないため 基本的で明確な反応機構を解析できる利点がある。 


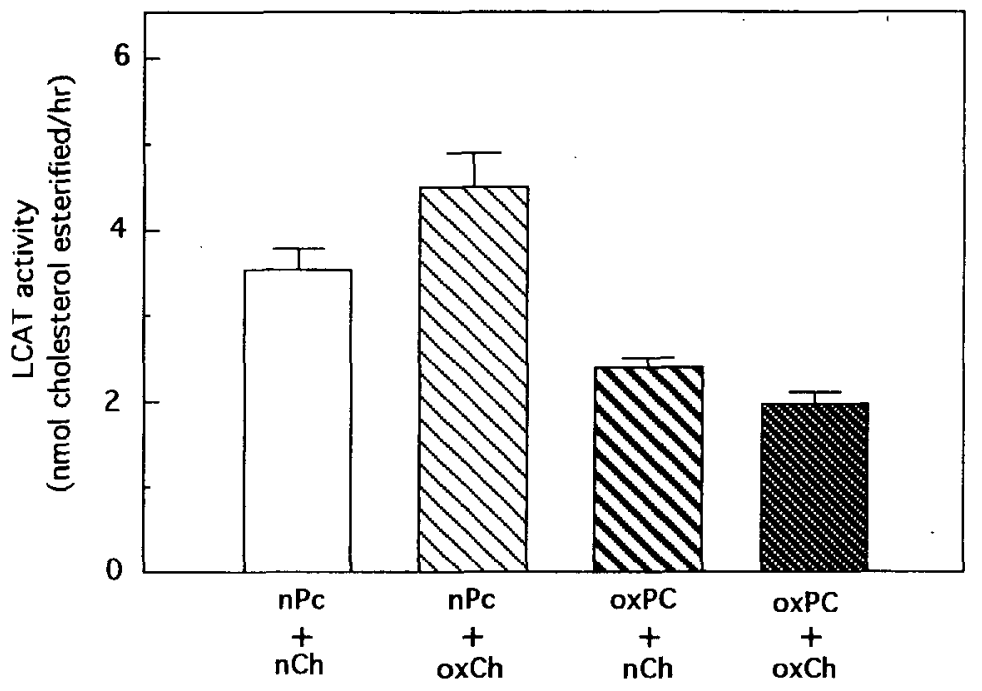

Fig. 5. Effect of oxidized phosphatidylcholine and oxidized cholesterol on LCAT activity. Vesicle solutions were prepared and oxidized by incubation with $2 \mathrm{mM} \mathrm{AAPH}$ for various times at $37^{\circ} \mathrm{C}$. Phosphatidylcholine and cholesterol were extracted from vesicle or oxidized vesicle solutions and reconstituted vesicle solutions prepared from these lipids. Four kinds of vesicle solution were prepared (see figure), and then used as substrate for the LCAT reaction. LCAT activity was measured using purified enzyme and cofactor in vesicle solution. Values shown are mean $\pm S E M$ of triplicate observations. $\mathrm{nPc}$, native phosphatidylcholine; $\mathrm{nCh}$, native cholesterol; oxPc, oxidized phosphatidylcholine; oxCh, oxidized cholesterol. (文献30)

には apo A-I の変性のような HDL の高度の酸化は必ずし屯必要ではないことを示してい る。また LCAT 活性が酸化時間に応じて急激に低下したことから，LCAT 活性は基質の 酸化によって大きく変動を受けるものと考えられる。

次に，LCATの基質よなりうる PC とコレステロールのうち，いずれの酸化がより大き く LCAT 活性に影響しているかを検討した。酸化したリポソームから脂質を抽出して酸 化PCおよび酸化コレステロールを分離し，これと未酸化リポソームから抽出したPCあ るいはコレステロールとを組み合わせてリポソームを再び調製し，これらを基質として LCAT 活性を測定した。Fig. 5 に示したように，PCのみを酸化したリポソームを用い た場合で LCAT 活性は低下したのに対し，コレステロールのみを酸化したリポソームを 用いた場合では活性は低下せず，むしろ上昇の傾向がみられた。これらの結果から，LCAT の基質になる HDL 表面の構成脂質のうち, PC の酸化が LCAT 活性の低下に大きく影響 を及ぼすものと考えられる。

\section{2-3 生体内で発生したフリーラジカルの血漿 LCAT 活性に及ぼす影響}

これまで，ヒト血墏および標準 LCAT活性测定系におけるフリーラジカル発生剂 
（AAPH）の LCAT 活性に及ぼす影響を in vitro で検討してきた。ここでは，生体内での 脂質の過酸化による LCAT 活性の変動をみるために, AAPH をラットに投与し，生体内 での脂質過酸化が実際に血漿 LCAT 活性に影響しうるか否か，またこの場合，共存させ た抗酸化ビタミンの挙動についても検討した。

実験動物として SD 系雄ラット6 週齢を用い，AAPH投与群 $(\mathrm{AAPH} 50 \mathrm{mg} / \mathrm{kg}$ BW を腹腔内投与)，ビタミンE (V.E) $+\mathrm{AAPH}$ 投与群（AAPH投与の 24 および 6 時間前に $\alpha$ -tocopherol $100 \mathrm{mg} / \mathrm{kg}$ BW を経口投与)，ビタミンC (V.C) + AAPH投与群（AAPH投 与の 24 および 6 時間前に L-ascorbic acid $100 \mathrm{mg} / \mathrm{kg}$ BW を経口投与)，コントロール群 （生理食塩水を腹腔内投与），を設け，1群各 5 匹の 4 群とした。AAPH 投与後，12時間 の絶食を行い，エーテル麻酔下で腹大動脈から採血した。血漿を分離し，血漿脂質，リポ タンパク質プロフィールおよび血漿 LCAT 活性を測定した。

Fig. 6 に示すように，AAPH の腹腔内投与により，LDL と HDL は約 $50 \%$ と急激に減 少した。これはin vivoで急性的な脂質過酸化が起こったため, 酸化変性したりポタンパ ク質が速やかに異化されたことによるあのであると思われる。しかしながら，抗酸化ビ夕 ミンである V.E，V.Cの前投与により LDL.の隇少は完全に，HDL は部分的に防禦され た。脂質過酸化の指標としての TBARS 值は Fig. 7 に示した。LDL，HDL ともに AAPH 投与群でコントロール群と差が見られず，V.E，V.C の前投与によりむしろ増加したが， これは AAPH 投与群では酸化変性を受けたリポタンパク質がほとんど排泄されてしまっ たためであると思われる。事実，AAPH 投与 5 時間後では，TBARS 值はコントロール

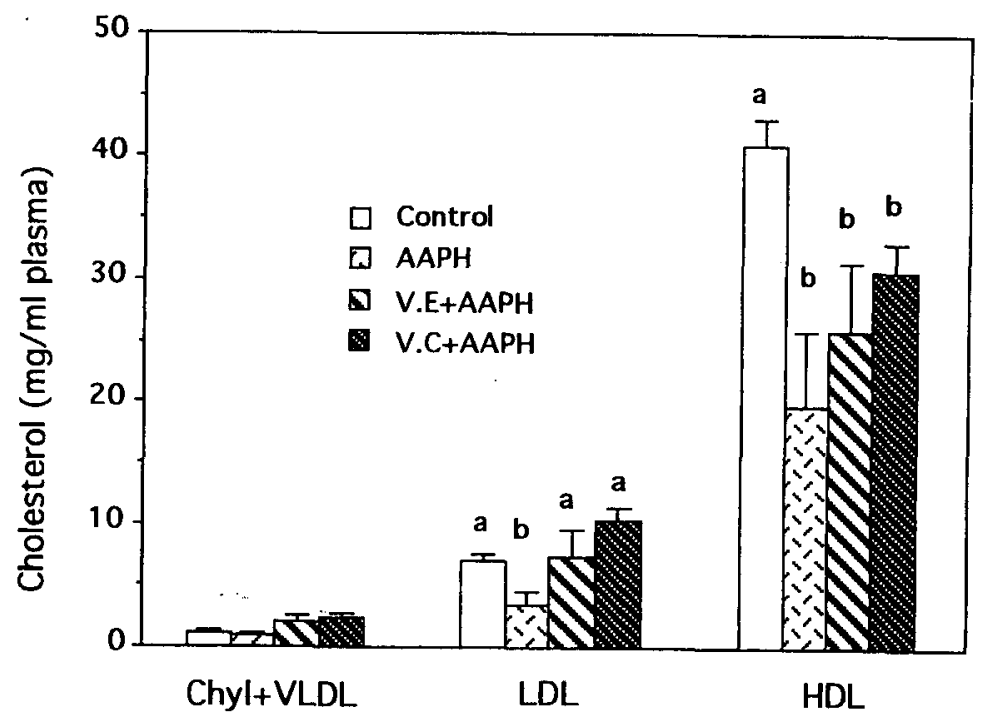

Fig. 6. Effect of AAPH administration on plasma lipoproteins cholesterol in SD rats. Results given as mean with standard error. Values not sharing same letter are significantly different at $p<0.05$. 


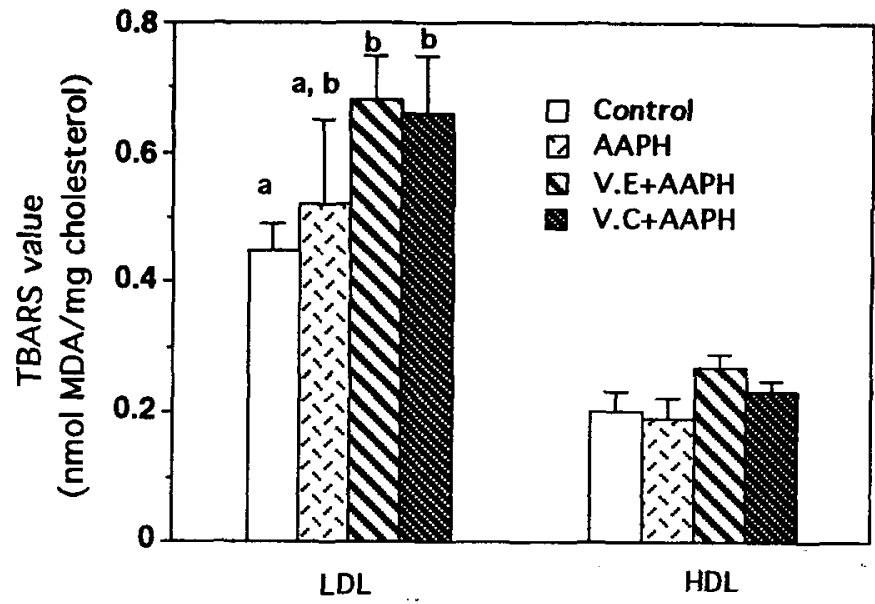

Fig. 7 Effect of AAPH administration on TBARS values of lipoproteins in SD rats.

Results given as mean with standard error. Values not sharing same letter are significantly different at $p<0.05$.

群に対し AAPH 群で有意に增加していた。一方，血漿 LCAT 活性はAAPH 投与群では コントロール群に比べ，1/2と顕著に減少した。しかしながら, V.E+AAPH 群ではこれ が回復の傾向にあり，V.C+AAPH 群ではこの減少は完全に防禦された（Table I）。こ のことから，血漿LCAT 活性は生体内で発生したフリーラジカルによって大きな抑制を 受けること，またその防御には抗酸化剂，特にV.C の常時存在することが特に有効であ ることが示された。

Table I Effect of AAPH administration on plasma LCAT activity.

\begin{tabular}{lc}
\hline Groups & $\begin{array}{c}\text { LCAT activity } \\
\text { (nmol cholesterol esterified } / \mathrm{ml} / \mathrm{hr} \text { ) }\end{array}$ \\
\hline Control & $70.84 \pm 8.26{ }^{\mathrm{a}}$ \\
AAPH & $36.97 \pm 2.56 \mathrm{~b}^{\mathrm{b}}$ \\
V.E+AAPH & $50.62 \pm 7.48$ a,b \\
V.C+AAPH & $79.21 \pm 7.35$ a \\
\hline
\end{tabular}

Results given as mean with standard error.

Values in the same row not sharing same superscript letter are significantly different at $\mathrm{p}<0.05$. 


\section{3. 酸化脂質と LCAT}

リン脂質は脂質過酸化を受ける之様々な反応産物を生じ，その中でむリン脂質骨格を残 したもの屯数多く知られている。リン脂質七ドロペルオキシド（PC-OOH）はフリーラ ジカルの供給源として組織障害の原因になるもの上考えられ, また短鎖脂肪酸分解物を含 む屯のの中には, 血小板活性化因子（Platelet-activating factor；PAF）の活性や細胞 障害性を有するもの，LDLなどのタンパク質を修飾するものも存在する。 PC-OOH は各 種疾患患者の血整や組織などに検出されており, 老化, 脳疾患, 動脈硬化などの病態之深 く関わっているものと考えられている。

LDL 中の PC-OOH 量は脂質過酸化によって増加するが31-33)，健常者の血漿中でのPCOOH濃度は低い。これはPC-OOHが安定性に欠けるためである之考えられているが ${ }^{34,35)}$, ホスホリパーゼ $\mathrm{A}_{2}{ }^{36,37)} \mathrm{PAF}$ アセチルヒドロラーゼ ${ }^{38,39)}$, 血漿グルタチオンペルオキ シダーゼ ${ }^{40-42)}$ のように $\mathrm{PC}-\mathrm{OOH}$ の酸化修飾された脂肪酸部分を加水分解して除去する醉 素もいくつか知られている。 HDLに結合性を持つ酵素としては，パラオキサナーゼが PC -OOHを切断することによって LDL の酸化抑制と LDL 中の酸化脂質の蓄積を防いでい ることが報告されており ${ }^{43)}$ ，その作用によって HDL は LDL を酸化から防御していると 考えられている ${ }^{44,16,45)}$ 。また, LCATについても，PC-OOH から CE-OOH が生成する との報告があり ${ }^{46)}, \mathrm{CE}-\mathrm{OOH}$ の蓄積した HDL は速やかに肝臓へと排泄され， CE- $\mathrm{OOH}$ は肝臓の Nonlisosomal component で速やかに異化されることから 質の代謝酵素としての役割が期待されている。

最近, Subbaiah 等は, 酸化状態ではコレステロールへの長鎖アシル基の転移が低下し て, 酸化生成物である短鎖脂肪酸の Lyso-PCへの転移活性が増加することを示し, 酸化

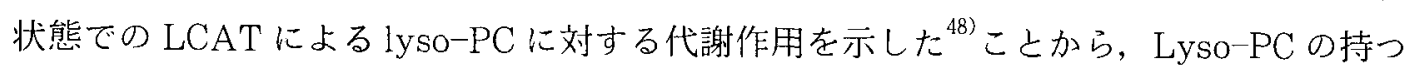
毒性の LCATによる軽減作用が示唆されている。

一方，コレステロールの酸化生成物である酸化コレステロールの HDLによる代謝の可 能性については, 現在のところ明確な見解はなされていない。酸化コレステロールの動脈 硬化症への関与では, その動脈硬化惹起性と血管障害性の両面から深く関わっていると考 えられている。ヒト動脈硬化病変部位に酸化コレステロールが検出されること ${ }^{49)}$, 加齢や 動脈硬化の進展と関連して酸化コレステロールの脂肪酸エステルが血管壁で増加すること が報告されており，ヒ卜血漿中には種々の酸化ステロール ${ }^{51,527} や \mathrm{CE}-\mathrm{OOH}$ 等のコレステ ロールエステル酸化生成物 ${ }^{34)}$ の存在が確認されている。ここで, 27-ヒドロキシコレステ

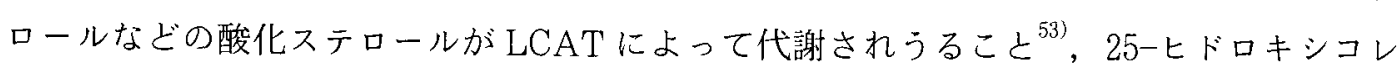
ステロールがLCATによってエステル化されることにより，その細胞等への移行が抑制 されること年，などから，酸化ステロールが LCATによって代謝されている可能性が考 えられ，LCATによって酸化ステロールがエステル化されるこよにより，その生体から 
の排除の促進と, HDL 中に閉じこめることによる毒性軽減作用が考えられる。さらに, 酸化コレステロールで飽和した HDLでは細胞からのコレステロール引き抜き能が減少す るとの報告があることから ${ }^{55)}$ HDLのコレステロール引き抜き能の維持においても LCAT によるエステル化反応の意義は大きく，今後の研究が期待される。

\section{4. おわりに}

血漿中のフリーラジカルによって，LDL 同様に HDL 屯酸化を受けることが知られて おり，最近になって酸化によるHDL 代謝の変化上，その動脈硬化症の進展におよぼす影 響について焦点が当てられつつある。HDL 上で反応している酵であるLCAT上リポタ ンパク質の酸化との関連については, HDL の酸化による apo A-I の変性によって LCAT の活性化作用が失われるとの報告 ${ }^{25)}$ や，いくつかの最近の研究によってLCAT の酸化脂 質代謝酵素としての可能性が示されているものの，その生体内での意義は未だ不明である。 筆者らは，LCAT 反応は基質の酸化に鋭敏であり，その構成脂質であるリン脂質の酸化 によって活性は大きく低下すること，さらに基質自体の酸化にとよ゙まらず，酸化リポタン パク質の存在により LCAT 反応が大きく阻害されることを示した。すなわち，血漿中の フリーラジカルの生成による酸化 LDL および酸化 HDL の生成が, 粥状動脈硬化症の修 復作用の主役である，HDL によるコレステロール逆転送系，特に LCATによるコレステ ロールエステル化反応を抑制し，コレステロール逆転送系の停滞をむたらす可能性を示し た。ここで, HDLによる脂質逆転送系は生体内でのもっとも優れた動脈硬化抑制機構之 して機能していることから，血墏中のフリーラジカルの生成とそれによるリポタンパク質 の酸化がこの HDLを介したコレステロール逆転送系によ゙のような影響をおよぼすかにつ いては，今後更に検討すべき課題である。

\section{<参考文献 $>$}

1) Glomset JA. J Lipid Res, $9:$ 155-167, 1968.

2) Glomset JA and Norum KK. Adv Lipid Res, $11: 1-65,1973$.

3 ) Stokke KJ. Atherosclerosis, $19: 393-406,1974$.

4) Jonas A. Biochim Biophys Acta, 1084 : 205-220, 1991.

5) Fielding CJ, Shore VG and Fielding PE. Biochem Biophys Res Commn, $46: 1493$ $-1498,1972$.

6) Norum KR, Glomset JA, Nichols AV, Forte T, Albers JJ, King WC, Mitchell CD, Applegate KR, Gong EL, Cabana V And Gjone E. Scand J Clin Lab Invest, 35 : Suppl 142, 31-55, 1975.

7) Albers JJ. Scand J Clin Lab Invest, 38 : Sppl 150, 48-52, 1978. 
8) Doi $Y$ and Nishida T. Methods in Enzymol, $71: 753-767,1981$.

9) McLean J, Fielding C, Drayna D, Dieplinger H, Baer B, Kohr W, Henzel W and Lawn R. Proc Natl Acad Sci USA, 83 : 2335-2339, 1986.

10) Furukawa $Y$ and Nishid T. J Biol Chem, 254:7213-7219, 1979.

11) Jonas A, Sweeny SA. and Herbert PN, J Biol Chem, 259 : 6369-6375, 1984.

12) Hida $\mathrm{Y}$, Furukawa $\mathrm{Y}$, Urano $\mathrm{T}$, Kim $\mathrm{H}-\mathrm{J}$, and Kimura $\mathrm{S}$. Biosci Biotech Biochem, 57 : 1111-1114, 1993.

13) Pownall HJ, Pao $Q$ and Massey JB. J Biol Chem, $260: 2146-2152,1985$.

14) Pownall HJ, Pao Q. Brockman HL and Massey JB. J Biol Chem, 262 : 9033-9036, 1987.

15) Jonas A, Zorich NL, Kezdy KE and Trick WE. J Biol Chem, 262 : 3969-3974, 1987.

16) Parthasarathy S, Barnett $J$ and Fong LG. Biochim Biophys Acta, 1044 : 275-283, 1990.

17) Reyftmann JP, Santus R, Mazière JC, Morliere P, Salmon S, Candide C, Mazère C and Haigle J. Biochim Biophys Acta, 1042 : 159-167, 1990.

18) Wang XL, Dudmann NP, Wang J and Wilklen DE. Clin Chem, $35: 2082-2086$, 1989.

19) Marcel YL, Jewer D, Leblond L, Weech PK and Milne RW. J Biol Chem, 264 : 19942-19950, 1989.

20) Anantharamaiah GM, Hughes TA, Iqbal M, Gawish A, Neame PJ, Medley MF And Segrest JP. J Lipid Res, 29 : 309-318, 1988.

21) Alomar $Y$, Nègre-Salvayre A, Levade $T$, Valdiguiè $P$ and Salvayre R. Biochim $B$ iophys Acta, 1128 : 163-166, 1992.

22) Azizova OA, Panasenko OM, Vol'Nova TV and Vladimirov YA. Free Radic Biol Med, $7: 251-257,1989$.

23) Nagano Y, Arai H and Kita T. Proc Natl Acad Sci USA, 88 : 6457-6461, 1991.

24) Samon S, Mazère C, Auclair M, Theron L, Santus R and Mazièr J-C. Biochim Biophys Acta, 1125 : 230-235, 1992.

25) Mazièr JC, Myara I, Salmon S, Auclair M, Haigle J, Santus R and Mazièr C. Atherosclerosis, $104:$ 213-219, 1993.

26) McCall MR, Van den Berg JJ, Kuypers FA., Tribble DL, Krauss RM, Knoff LJ and Forte TM. Arterioscler Thromb, 14 : 248-253, 1994.

27) Bielicki JK, McCall MR, Van den Berg JJ, Kuypers FA and Forte TM. J Lipid Res, 36 : 322-331, 1995. 
28) Musanti R and Ghiselli G, Arterioscler Thromb, 13 : 1334-1345, 1993.

29) Kamiyama S, Kim H-J and Furukawa Y. Biosci Biotech Biochem, 60 : 580-583, 1996.

30) Kamiyama S, Yamato T and Furukawa Y. Biosci Biotech Biochem, 62 : 941-946, 1998.

31) Frei B, Stocker R and Ames BN. Proc Natl Acad Sci USA, 85 : 9748-9752, 1988.

32) Sato K, Niki E and Shimasaki H. Arch Biochem Biophys, 279 : 402-405, 1990.

33) Bowry VW, Stanley KK And Stocker R. Proc Natl Acad Sci USA, 89 : 1031610320, 1992.

34) Yamamoto Y And Niki E. Biochem Biophys Res Commun, 165 : 988-993, 1989.

35) Yamamoto $Y$ and Ames BN. Free Radic Biol Med, 3: 359-361, 1987.

36) Parthasarathy S, Steinbrecher UP, Barnett J, Witztum JL and Steinberg D. Proc Natl Acad Sci USA, 82 : 3000-3004, 1985.

37) Parthasarathy S and Barnett J. Proc Natl Acad Sci USA, 87 : 9741-9745, 1990.

38) Stremler KE, Stafforini DM, Prescott SM, Zimmerman GA and McIntyre TM. J Biol Chem, 264: 5331-5334, 1989.

39) Streinbrecher UP and Pritchard PH. J Lipid Res, 30 : 305-315, 1989.

40) Yamamoto $Y$ Nagata $Y$, Niki E, Watanabe $K$ and Yoshimura S. Biochem Biophys Res Commun, 193 : 133-138, 1993.

41) Yamamoto $Y$ and Takasaki K. Arch Biochem Biophys, 305 : 541-545, 1993.

42) Esworthy RS, Chu FF, Geiger P, Girotti AW and Doroshow JH. Arch Biochem Biophys, $307: 29-34,1993$.

43) Mackness MI, Arrol S, Abbott C and Durrington PN. Atherosclerosis, $104: 129$ $-135,1993$.

44) Banka CL. Curr Opin Lipidol, $7:$ 139-142, 1996.

45) Mackness MI, Mackness B, Durrington PN, Connelly PW and Hegele RA Curr Opin Lipidol, $7: 69-76,1996$.

46) Nagata Y, Yamamoto Y and Niki E. Arch Biochem Biophys, 329:24-30, 1996.

47) Sattler W and Stocker R. Biochem J, $294: 771-778,1993$.

48) Subbaiah PV and Liu M. Biochim Biophys Acta, 1301 : 115-126, 1996.

49) Jacobson MS, Nair PP,..Naseem SM, Smith TD and Heald FP. Pediatric Res, 15 : $535,1981$.

50) Teng JI and Smith LL. Texas Rpts Biol Med, 33 : 293-301, 1975.

51) Brooks CJW, McKenna RM, Cole WJ, MacLachlan J and Lawrie TDV. Biochem 
Soc Trans, $11: 700-701,1983$.

52) Javitt NB, Kok E, Burstein S, Cohen B and Kutscher J. J Biol Chem, 256 : 12644 $-12646,1981$.

53) Szedlacsek SE, Wasowicz E, Hulea SA, Nishida HI, Kummerow FA and Nishida T. J Biol Chem, 270 : 11812-11819, 1995.

54) Lin CY and Morel DW. J Lipid Res, 37 : 168-178, 1996.

55) Gesquiere L and Loreau N Blache D, Free Radic. Biol Med, 23 : 541-547, 1997.

56) Stokke KT and Norum KR. Scand J Clin Invest, $27: 21-27,1971$.

57）板倉 弘重. 新生化学実験講座 4, 脂質 I 中性脂質とリポタンパク質, 293-295, 1993.

58）古川 勇次、肥田 嘉文. 新生化学実験講座 4 , 脂質I 中性脂質とリポタンパク質, 296 $-302,1993$. 